Volume II, No.2 Desember 2012/1433 H

\title{
MANAJEMEN SDM DALAM PRESPEKTIF EKONOMI ISLAM : TINJAUAN MANAJEMEN SDM DALAM INDUSTRI BISNIS
}

\author{
Teguh Suripto \\ (Dosen STIA Alma Ata Yogyakarta)
}

\begin{abstract}
Management is one branch of economics that plays an important role in the successful management of an organization or company. Implementation of the company's management can improve the effectiveness and efficiency of resource companies or organizations so as to achieve the goal or vision of a better company. Islam is one religion the religion professed by the majority of the Indonesian population, have given color to every aspect of life of its adherents. Started in terms of religious, political, social and economic. Conventional economic outlook puts worldliness course, has not looked at his spiritual needs. So that employees only be the object of the company and not be subject to the company. With the implementation of the Human Resources Management Islam, the employee will be subject to the company so that they are able to participate actively for the betterment of the company. Islamic economic system in implementing human resource management, based on the harmony or balance between the need to do material and human ethics. Islamic Economic System not forget the main features of human progress, which is dependent on the extent to which the smooth coordination and harmony between the moral and material aspects of human life.
\end{abstract}

Key word : Management SDM, Islamic Economic, Recruitment, Selection, training and development

\section{A. Pendahuluan}

Manajemen merupakan salah satu cabang dari ilmu ekonomi yang memegang peranan penting dalam keberhasilan pengelolaan suatu organisasi atau perusahaan. Penerapan manajemen pada perusahaan dapat meningkatkan efektifitas dan efisiensi sumber daya perusahaan atau organisasi sehingga mencapai hasil yang lebih baik. Sejak abad ke 17 manajemen baik sebagai ilmu sains maupun praktik merupakan salah satu faktor utama pendorong perkembangan industry - industry besar.(Fuad Ma'ud, 2008). Berkat perkembangan sains, pengelolaan sumber daya yang dimiliki oleh manusia dapat dilakukan dengan baik.

Istilah manajemen pertama kali dikenalkan oleh Taylor pada tahun 1911. Ilmu ini telah menyebar ke berbagai belahan dunia tanpa mengenal batasan Negara. Metode manajemen klasik oleh taylor banyak diterapkan dalam berbagai kegiatan organisasi untuk meningkatkan produktivitas kerja.(Husaini, 2009).Dalam perkembangannya, walaupun manajemen 
ditemukan oleh dunia barat, tetapi seiring dengan menyebarnya dunia industry, manajemen dikenal dan diterapkan oleh hampir seluruh perusahaan / organisasi di seluruh dunia. Sebagai ilmu, manajemen bukanlah sesuatu yang bebas nilai. Manajemen sebagai produk peradaban manusia bukanlah sains yang bebas nilai (value free science). Manajemen yang dikembangkan oleh ahli barat seperti Amerika Serikat, sudah tentu dilandasi oleh pandangan dunia barat, dan mengandung nilai - nilai yang diyakini dan dianut oleh para ahli yang mengembangkannya. Sebagai contoh, di dalam peradaban barat, Eropa, dan Amerika, sain dipisahkan dari agama. (Fuad Mas'ud, 2008).

Disamping persoalan manajemen, seringkali perusahaan juga berhadapan dengan persoalan ekonomi yang lebih luas, misalnya tentang ketidak adilan ekonomi. Persoalan ini telah menimbulkan kekecewaan di antara beberapa pihak. Pemerintah yang dianggap sebagai pembuat dan pengendali aturan seringkali kebijakannya dianggap kurang berpihak kepada dunia usaha. Oleh karena itu perusahaan perlu memperkuat diri dengan kemampuan manajerialnya yang baik. Dalam kondisi yang seperti itu, banyak tokoh berupaya memasukan norma - norma agama dan nilai nilai keadilan ke dalam system perekonomian Indonesia. (Prawiranegara,1966). Lebih dari itu, masyarakat dalam jumlah yang besar memiliki harapan yang pasti dari organisasi dan menggunakan pengaruhnya terhadap organisasi, melalui berbagai bidang formal maupun nonformal. Institusi politik, sosial dan ekonomi, seperti struktur ekonomi, serikat perdagangan, system pendidikan, semuanya dapat digunakan sebagai pengaruh dalam organisasi.(Hofstede,1980).

Agama merupakan salah satu hal yang memberikan pengaruh yang besar terhadap perkembangan masyarakat terutama dalam hal budaya dan nilai- nilai sosial di dalamnya (Social values). Pengaruh dari nilai - nilai yang ada di masyarakat (Social Values) meupakan keyakinan dan nilai nilai yang dominan dari masyarakat yang luas (misalnya kebebasan individu, kolektivisme, kesopanan, kebersihan dan sebagainya.(Fuad Mas'ud,2011). Agama Islam sebagai salah satu agama yang dianut oleh mayoritas penduduk Indonesia, telah memberikan warna kepada setiap aspek kehidupan pemeluknya. Dimulai dari segi ibadah, politik, sosial dan ekonomi. Walaupun Indonesia tidak menggunakan agama sebagai dasar Negara. Konsep ajaran agama ini dijalankan secara individual oleh pemeluknya. Masyarakat muslim percaya bahwa bahwa keselamatan dan keberuntungan akan dicapai ketika kaum muslim menerapkan ajaran agama dalam kehidupan. Al Quran menegaskan kepada setiap muslim untuk senantiasa terikat dengan aturan aturan Alloh SWT dalam setiap aspek kehidupan yang dijalankannya.

Dengan berlandaskan pada konsep tersebut daiatas, maka pengelolaan Sumber Daya Manusia sebagai sebuah unsur manajemen dalam perusahaan, memiliki dasar yang kuat untuk menerapkan syariat atau tuntunan dalam Islam dalam pengelolaan SDM. Dengan demikian system syariah dalam manajamen akan memberikan efek yang baik. Sistem syariah atau system ekonomi syariah di Indonesia pada tahun 2010 telah mulai tumbuh danberkembang dengan baik. Masyarakat mulai mengenal dan memanfaat industry yang dikelola dengan system syariah, misalnya

Manajem en SDM 
perbankan, asuransi, dan bahkan perusahaan manufaktur atau ritel yang menerapkan system syariah. Namun demikian kendala utama dalam system syariah adalah pengelolaan Sumber Daya manusia. SDM sebagai pilar utama perusahaan masih banyak dikelola tanpa konsep agama Islam. Sehingga masih dijumpai praktik pengelolaan SDM yang kurang berkeadilan dan kurang mensejahterakan.

Salah satu penyebab dari hal itu adalah penyebaran konsep manajemen di berbagai Negara sangat dipengaruhi oleh budaya yang berkembang di masing - masing Negara yang disebut sebagai budaya nasional (National Culture). Budaya nasional memberikan bentuk dan pengaruh terhadap semua proses yang berkembang didalmnya.(Larasati, Fuad, 2010). Oleh karena itu dalam sebuah Negara muslim seperti Indonesia, melalui budaya nasionalnya dapat mempengaruhi perusahaan. MSDM (Manajemen Sumber Daya Manusia) merupakan salah satu aspek pada organisasi / perusahaan, dapat dipengaruhi pola pengelolaannya melalui budaya nasional yang dianut oleh Negara tersebut. Dengan refleksi tersebut nilai - nilai Islam akan diimplementasikan secara nyata di dunia bisnis atau industry.

Dengan dasar konsep pemikiran tersebut akan dikaji mengenai nilai - nilai Islam dan aplikasinya dalam Manajemen Sumber Daya Manusia.

\section{B. Kajian Teori}

\section{Manajemen Sumber Daya Manusia}

Religions are generally considered as specific system of beliefe, workship, and conduct. However, Islam signifies religion as a sosial orser and way of life which aims at producing a unique personality and a distinct culture for society. (Metle,dalam Junaidah Hasyim, 2009). Agama merupakan pertimbangan umum sebagai system yang spesifik tentang kepercayaan ibadah dan tingkah laku. Bagaimanapun juga, agama Islam adalah jalan kehidupan yang bertujuan menghasilkan personality yang unik dan sebuah kebudayaan yang berbeda untuk masyarakat. Agama sebagai jalan kehidupan memberikan tuntunan kepada pemeluknya agar selalu hidup dijalan agama. Islam tidak hanya memberikan tuntunan dalam hal ibadah, tetapi juga dalam semua aspek kehidupan manusia. Seluruh aspek kehidupan manusia dimulai dari ibadah, sosial, budaya, politik dan ekonomi semua diatur oleh tuntunan - Nya. Dalam hal ekonomi Islam memiliki konsep yang berbeda dengan konsep ekonomi lainnya.(Larasati, Fuad, 2010). Demikan pula dengan tenaga kerja atau SDM (Sumber Daya Manusia)

Tenaga kerja atau Sumber Daya Manusia, adalah sebagai faktor produksi mempunyai arti yang besar. Karena semua kekayaan alam tidak berguna bila tidak dieksploitasi oleh manusia. Oleh karena itu setiap perusahaan seharusnya sangat memperhatikan SDM sebagai salah satu

Teguh faktor produksi. Al Qur'an telah memberikan perhatian yang lebih Suripto terhadap manusia, hal ini dapat dilihat dari petikan ayat dala surat An Najm. (Afzalur Rahman, 1995), yang artinya : 
“Dan bahwasannya seorang manusia tiada memperoleh selain apa yang telah diusahakannya" (An Najm : 39).

Diriwayatkan dalam ayat tersebut bahwa salah satu cara untuk memperoleh sesuatu dari ala mini ialah melalui kerja keras. Semakin bersungguh - sungguh dia bekerja maka semakin banyak harta yang akan diperolehnya. Prinsip tersebut dijelaskan lagi didalam surat An Nisaa.,melalui firman Allah SWT, yang artinya sebagai berikut :

"Untuk lelaki ada bagian dari usaha yang dikerjakannya dan untuk wanita ada bagian pula yang dari usaha yang dikerjakannya." (An Nisaa : 32)

Dari ayat tersebut tersebut dapat diketahui bahwa setiap orang diberi ganjaran menurut apa yang telah mereka kerjakan. Siapa yang bekerja keras akan mendapat ganjaran menurut apa yang telah mereka kerjakan. Dengan demikian isi Al Quran, sesungguhnya memiliki aplikasi praktis pada keseluruhan bidang kehidupan manusia. Tidak hanya sebagai petunjuk ritual persoalan metafisik dan pembinaan ketaqwaan personal saja akan tepai juga pada semua aspek kehidupan termasuk bidang ekonomi.(Larasati, Fuad, 2010).

Kemajuan ilmu pengetahuan dan teknologi di Negara maju maupun Negara berkembang sangat ditentukan oleh perkembangan Manajemen Sumber Daya Manusia. Istilah Manajemen Sumber Daya Manusia dapat diartikan mengelola sumber daya manusia. Dari keseluruhan sumber daya yang tersedia dalam suatu organisasi baik organisasi public maupun swasta. (Faustino, 2000). Sumber daya manusialah yang sangat penting dan menentukan, sumber daya manusia merupakan satu - satunya sumber daya yang memiliki akal, perasaan, keinginan, kemampuan, ketrampilan, dan pengetahuan. Selain itu Manajemen Sumber Daya Manusia juga diartikan kemampuan manusia untuk mengelola sumber daya organisasi yang dimilikinya seperti bahan baku, uang, dan informasi, sehingga diperoleh kinerja yang baik. (Snell, 2004).

Manajemen Sumber Daya Manusia sebenarnya merupakan suatu gerakan pengakuan terhadap pentingnya unsur manusia sebagai sumber daya yang cukup potensial yang perlu dikembangkan sehingga mampu memberikan kontribusi yang maksimal bagi perusahaan. Manajemen Sumber Daya Manusia dapat dilihat dari berbagai prespektif, diantaranya prespektif politik, ekonomi, teknologi, dan sosial budaya. (Moses K. Kiggundu, 1989). Dari berbagai prespektif tersebut, prespektif ekonomi memberikan pengertian yang lebih luas bahwa Manajemen Sumber Daya Manusia adalah proses penarikan, seleksi, pengembangan, pemeliharaan, dan penggunaan Sumber Daya Manusia untuk mencapai tujuan - tujuan individu maupun organisasi. (Hani Handoko, 1998).

\section{Manajemen SDM dalam Prespektif Ekonomi Islam}

Dalam dunia industri, saat ini manajemen menjadi suatu hal yang sangat penting dalam menjalankan usaha, terlebih manajemen SDM. Melalui manajemen diupayakan inovasi - inovasi baru yang mampu memberikan solusi bagi perkembangan dunia industry, khususnya untuk menghadapi persaingan yang semakin ketat. Teorisasi tentang manajemen telah berkembang sejalan dengan pertumbuhan industry di awal abad 19 .

Manajem en SDM 
Teori tersebut diantaranya teori teori manajemen ilmiah, teori hubungan kemanusiaan, teori birokrasi Max weber, teori analisis organisasi, dan teori lainnya. Kesemua teori tersebut telah menghasilkan teori manajemen modern yang peka terhadap kritik.(Abu Sinn, 2006). Dengan demikian perbedaan paham antar teorisasi tersebut, telah menghasilkan falsafah manajemen yang beragam, yang pada akhirnya akan lebih memperkuat manajemen sebagai sebuah ilmu. Ada beberapa perbedaan yang dapat terlihat dari kajian teorisasi tersebut, diantaranya :

1. Munculnya anggapan bahwa individu karyawan merupakan makhluk yang rasional, sehingga dia akan termotivasi dengan nilai materi (Insentif Gaji), Oleh karenanya memberikan gaji yang tinggi merupakan sarana yang baik untuk meningkatkan produktivitas.

2. Karyawan dianggap tidak peduli dan tidak focus terhadap tujuan perusahaan/organisasi dan hanya focus terhadap kebutuhan fisiologis, sehingga perusahaan berkewajiban memenuhi kebutuhan dasar mereka. Selain itu perusahaan berupaya mengajak mereka untuk duduk bersama menyatukan tujuan dan mengikut sertakan mereka dalam mengambil keputusan guna memenuhi kebutuhan sosial dan psikologis mereka.

3. Kompetensi karyawan perlu ditingkatkan dengan training agar kinerja mereka optimal, dan produktivitas mereka meningkat. Karenanya perlu pengawasan terhadap mereka dan di samping itu perlu seleksi atau pemilihan karyawan yang tepat sesuai dengan kompetensi mereka. (Ruslan Abdul Ghofur, 2010)

\section{Kriteria Pemilihan SDM}

Dalam kajian Ekonomi Islam, penawaran atau proses rekruetmen tenaga kerja bergantung pada tiga faktor, yaitu:

\section{a. Kecakapan tenaga Kerja}

Dalam pandangan Ekonmi Islam, seorang tenaga kerja atau SDM harus memiliki kecakapan dalam bekerja. Pekerja harus memiliki keahlian dan ketampilan yang dapat meningkatkan keuntungan perusahaan. Islam sangat menjunjung tinggi hasil kerja yang cakap, dan diperintahkan kepada semua umat muslim untuk mengerjakan semua jenis pekerjaan dengan tekun dan sempurna. Pada umumnya keahlian seseorang akan sangat bergantung pada : (Afzalur Rahman, 1995)

\section{b. Kesehatan Moral dan fisik}

Kesehatan moral dan fisik ini sangat erat dengan kecakapan seseorang, SDM yang kuat, sehat tentu akan lebih cakap dibandingkan dengan tenaga kerja yang lemah. Sifat - sifat seorang pekerja yang cakap disampaikan dalam Al Quran yang artinya sebagai berikut :

"berkata seorang anaknya : "Hai bapakku, ambilah dia (Musa) jadi pekerja (menggembalakan ternak kita), karena yang sebaik - baik pekerja ialah yang kuat lagi jujur"(Al Qashash : 26).

Ayat tersebut member penjelasan kepada kita bahwa kekuatan fisik

Teguh

Suripto

243 yaitu kesehatan dan kejujuran (kebagusan akhlak) merupakan sifat yang diperlukan oleh seorang pekerja yang cakap. Sifat terseut dimiliki oleh Nabi Musa As., dan oleh karena itulah, beliau dicontohkan sebagai seorang pekerja yang cakap dan kuat. Sedangkan berkaitan dengan kesehatan 
moral, kejujuran menjadi tolok ukur yang dapat dilihat. Rosulullah sangat memji orang yang dapat dipercaya, seperti sabda beliau, yang artinya adalah :

"Saudagar yang jujur dan amanah akan termasuk kedalam golongan para rosul, orang saleh dan syuhada". (HR. Tirmidzi dan Ibnu Majah)

\section{c. Akal pikiran yang baik.}

Dengan akal pikiran yang baik seorang pekerja akan mampu mengembangkan idea tau gagasan untuk kemajuan perusahaannya. Akal pikiran yang sehat yaitu daya upaya seseorang didalam menilai dan mencetuskan segala sesuatu dengan cara sebijaksana mungkin. Sifat yang demikian di dalam Al Quran, disampaikan. Yang artinya sebagai berikut : : (Afzalur Rahman, 1995)

"Berkata Yusuf : “jadikanlah aku bendaharawan Negara (Mesir), sesungguhnya aku adalah seorang yang pandai menjaga lagi berpengetahuan". (QS Yusuf : 55)

Dari ayat tersebut dapat dipelajari bahwa akal pikiran yang baik, dalam islam sangat diperhatikan. Islam sangat mementingkan akal pikiran yang baik, karena akal merupakan alat yang diberikan oleh Alloh SWT, untuk menjadikan manusia sebagai makhluk yang lebih sempurna dari makhluk yang lain. Untuk itu akal yang baik akan menjadikan manusia lebih mampu mengembangkan dan meningkatkan derajat kehidupan bagi perusahaannya.

\section{Pelatihan dan Pengembangan}

Para karyawan baru biasanya telah kecakapan dan ketrampilan dasar yang dibutuhkan. Mereka adalah produk dari suatu sistem pendidikan dan mempunyai pengalaman yang diperoleh dari organisasi lain. Tidak jarang pula karyawan baru yang diterima tidak mempunyai kemampuan secara penuh untuk melaksanakan tugas - tugas mereka. Bahkan karyawan yang baru juga perlu menyesuaikan dengan organisasi dan orang - orangnya. (Hani Handoko, 1998). Secara umum ada dua tujuan utama program latihan dan pengembangan karyawan, yaitu : pertama latihan dan pengembangan dilakukan untuk menutup gap antara kecakapan dan kemampuan karyawan dengan permintaan jabatan dan kedua diharapkan program tersebut dapat meningkatkan efisiensi dan efektivitas kerja karyawan dalam mencapai sasaran kerja yang telah ditetapkan. (Hani Handoko, 1998)

Dalam pandangan Islam pendidikan dan pelatihan juga dapat meningkatkan kemampuan tenaga kerja. Tenaga kerja yang terlatih dan berpendidikan mampu bekerja lebih teliti daripada yang tidak memiliki ketrampilan dan pendidikan. Hal ini tertuang dalam firman Alloh SWT., dalam surat Al Baqarah, yang artinya : (Afzalur Rahman, 1995)

"Alloh menganugerahkan Al Hikmah (kepahaman yang dalam tentang Al Quran dan As Sunnah) kepada siapa yang dia kehendaki. Dan barang siapa dianugerahi Al Hikmah itu, dia benar - benar telah dianugerahi Al Hukmah itu, ia benar - benar telah dianugerahi karunia yang banyak. Dan hanya orang - orang yang berakalah yang dapat mengambil pelajaran." (Al Baqarah : 269)

Manajem en SDM 
Dari ayat tersebut, pendidikan dan pelatihan dianggap sebagai kebajikan dimana sifat - sifat tersebut menyamai harta dan kekayaan yang banyak. Lebih Lanjut Alloh SWR., menegaskan pentingnya pendidikan dan pelatihan tersbut dalam surat Az Zumar, yang artinya : : (Afzalur Rahman, 1995)

“(Apakah kamu hai orang - orang yang musyrik yang lebih beruntung) ataukah orang yang beribadah di waktu - waktu malam dengan sujud dan berdiri, sedangkan ia takut kepada (azab) akhirat dan mengharapkan rahmat Tuhannya?. Katakanlah : "Adakah sama orang - orang yang mengetahui dengan orang - orang yang tidak mengetahui?"sesungguhnya orang berakallah yang dapat menerima pelajaran". (Az Zumar : 9).

Jelas dalam ayat tersebut Alloh SWT., menyampaikan bahwa hasil pekerjaan dan kemampuan pekerja yang tidak terlatih tidak akan sama dengan hasil pekerjaan dari orang - orang yang terlatih.

\section{Pembahasan}

\section{Implementasi Manajemen SDM (MSDM) di perusahaan}

Banyak perusahaan, baik dalam sekala kecil, menengah dan besar, mengimplementasi MSDM. MSDM yang merupakan rangkaian dari kegiatan penarikan, seleksi, pengembangan, pelatihan, dan penggunaan Sumber Daya Manusia untuk mencapai tujuan - tujuan individu maupun organisasi. (Hani Handoko, 1998). Pada saat awal akan melakukan proses recruitment tenaga kerja, banyak perusahaan melihat terlebih dahulu Job Specification, yaitu kebutuhan yang diharapkan dari tenaga kerja, meliputi pengetahuan, ketrampilan, dan kemampuan yang harus dimiliki tenaga kerja untuk mengisi jabatan atau posisi tertentu. (Snell, 2004). Oleh karena itu unsur pengetahuan dan ketrampilan merupakan penilaian mutlak dari perusahaan terhadap calon tenaga kerja. Perusahaan selalu mendahulukan penilaian ketrampilan dan pengetahuan yang harus dimiliki oleh tenaga kerja, misalnya : latar belakang pendidikan, pengalaman kerja, pelatihan yang pernah diikuti, dan lain sebagainya. Unsur religious seseorang belum banyak di aplikasikan dalam proses recruitment.

Disamping Job specification, perusahaan juga memiliki Job Discription sebagai unsur untuk melakukan seleksi karyawan. Job Discription merupakan gambaran tentangpekerjaan, tugas dan tanggung jawab dari pekerjaan. Ketika seorang karyawan akan menduduki suatu jabatan tertentu, maka perusahaan akan melihat unsur yang harus dimiliki oleh pekerja terhadap pekerjaan tersebut. Ketentuan ini mengakibatkan karyawan cenderung hanya bekerja memenuhi ketentuan ketentuan yang ada, mereka tidak mampu berpikir lebih luas dan tidak memikirkan lagi unsur moralitas keagamaan. Karyawan bekerja sebagai faktor produksi, yang hanya menyelesaikan tugas - tugas yang dibebankan kepadanya. Seleksi karyan juga memanfaatkan unsure Job Discription sebagai Teguh penilaian utama. Seorang dianggap berhasil apabila dia mampu Suripto menjalankan tugas dengan baik, memenuhi target yang diberikan, sehingga karyawan banyak menjadi obyek bagi perusahaan, dan bukan subyek perusahaan. Sehingga karyawan hanya cenderung menyelesaikan 
tugas, dan mengejar target. Ruh rohaninya tidak terisi dengan makna kerja adalah ibadah., karena bekerja hanya sekedar mengejar makna duniawi.

Pola yang demikian mengakibatkan karyawan cenderung dianggap sebagai pihak yang lemah, tidak mampu memenuhi kebutuhan ekonomi dan spiritualnya. (Ruslan Abdul Ghofur, 2010). Disamping pola recruitment dan seleksi karyawan, perusahaan juga perlu melakukan pelatihan dan pengembangan karyawan. Karyawan perlu dilatih dengan ketrampilan yang lebih baik, dan jika perlu dikembangkan untuk kebutuhan dimasa depan. Ada dua tujuan dari proses seleksi karyawan, yaitu untuk mengurangi gap antara kecakapan dan kemampuan karyawan dengan permintaan jabatan dan peningkatan efisiensi dan efektifitas karyawan. Langkah - langkah pendahuluan dalam persiapan pelatihan dan pengembangan karyawan dapat di lakukan sebagai berikut : (Hani Handoko, 1998)

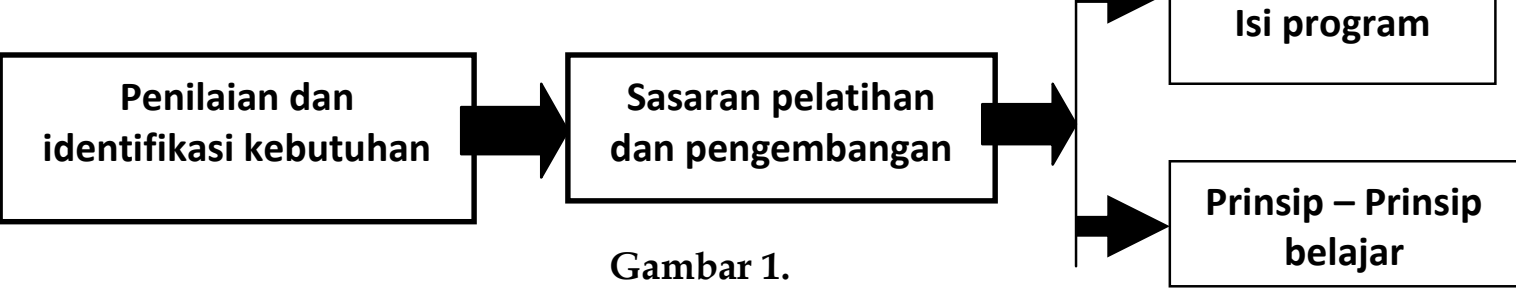

Langkah Dalam persiapan Program pelatihan dan pengembangan

Proses pelatihan dan pengembangan di awali dengan proses identifikasi kebutuhan perusahaan, selanjutnya akan diikuti oleh proses perumusan sasaran pelatihan dan pengembangan dan pada akhirnya akan ditentukan isi program dan prinsip pembelajaran. Seluruh langkah ini menggambarkan tahapan yang dilalui oleh perusahaan, yang pada akhirnya semua itu merupakan represntasi dari tujuan yang ingin dicapai dari perusahaan untuk mewujudkan visi dan misi perusahaan. Akan tetapi yang perlu diperhatikan adalah perumusan sasaran, pada tahap ini seringkali perusahaan hanya merumuskan tujuan duniawi semata. Tujuan untuk keperluan rohani belum banyak mewarnai sasarn yang ingin dicapai, sehingga pada sisi penyusunan program atau isi program hanya represntasi dari kebutuhan perusahaan, belum di sesuaikan dengan kebutuhan rohani karyawan. Kesenjangan inilah yang kemudian menjadikan karyawan hanya bekerja untuk keperluan perusahaan, belum mampu mewujudkan kebutuhan rohani, sebagai wujud ketakwaan kita kepada Alloh SWT.

\section{Manajemen SDM (MSDM) dalam Prespektif Islam.}

Agama Islam merupakan agama yang Rahmatan lil Alamin, memberikan rahmat, berkah dan kesejahteraan bagi semua umat di muka bumi ini. Oleh karena itu dasar pengelolaan perusahaan sudah semestinya berdasar pada prinsip tersebut. Termasuk dalam mengelola SDM atau karyawan. Hal yang harus diperhatikan dalam pengelolaan karyawan adalah (Afzalur Rahman, 2004).

a. Bekerja adalah hal yang mulia. Rosulullah S.A.W suatu saat pernah mencium tangan seorang sahabat ketika beliau mengetahui bahwa lelaki tersebut hitam (kasar) karena bekerja menggunakan martil, dan beliau sangat simpati mengetahuinya. (Usad ul Ghabah Takzirah Sa'ad Ansari)

Manajem en SDM

246 
b. Bekerja adalah untuk kesejahteraan bersama. Khalifah keempat Sayyidina Ali r.a. pernah berkata dengan bangga bahwa dia pernah mengetahui Rosulullah s.a.w. sedang lapar dan dia bekerja, supaya dapat membelikan makanan untuk beliau. Dia bekerja membersihkan lumpur di kebun seorang Yahudi di luar Madinah, dan memperoleh 17 kurma, karena mengangkat 17 ember air. Akhirnya mereka makan buah tersebut bersama - sama.

Kedua hal tersebut memberikan dasar yang kuat bagi seluruh karyawan bahwa perlunya pemikiran kesejahteraan bersama dan kemulian bersama dihadapan Alloh jika kita bekerja dengan sungguh - sungguh.

Dalam proses recruitmen, seleksi, pelatihan dan pengembanga karyawan semuanya memiliki dasar bahwa Alloh merupakan tujuan utama. Oleh karena itu manajemen yang memperlakukan karyawan hanya sebagai obyek perusahaan, dalam pandangan Ekonomi Islam dianggap manajemen yang lalai dari sifat adil yang semestinya menjadi dasar manajemen.manajemen harus memanusiakan manusia dan menempatkan manusia sebagai focus, tidak hanya sebagai faktor produksi semata. (Antonio, 2007).

Keharusan memperhatikan tuntunan Alloh dalam pengelolaan SDM perusahaan, didasari adanya kenyataan, bahwa masih banyak dijumpai perusahaan yang dengan sengaja mengeksploitasi karyawan sekedar untuk meningkatkan keuntungan perusahaan. Karyawan dieksploitasi sedemikian rupa, sehingga mereka benar - benar takut untuk menyampaikan ide, gagasan, harapan terhadap perusahaan. Banyak praktik tersebut kita jumpai, misalnya : Jam kerja yang sangat ketat, pemberian gaji yang belum dapat memberikan kesejahteraan, tekanan yang kuat bagi karyawan untuk mencapai target yang telah di tentukan perusahaan.

Islam sangat tidak memuji perlakuan tersebut, karena dalam kenyataannya system ekonomi Islam memang mendasarkan pada keselarasan atau keseimbangan yang dapat dilakukan diantara kebutuhan materialdan etika manusia. Sistem Ekonomi Islam tidak melupakan ciri pokok kemajuan manusia, yang bergantung kepada sejauh mana lancarnya koordinasi dan keharmonisan diantara aspek moral dan material dalam kehidupan manusia. (Afzalur Rahman, 1995). Dengan demikian praktik Manajemen SDM yang patut dilaksanakan adalah :

1. Pelaksanaan recruitment tenaga kerja atau SDM hendaknya dilakukan dengan memperhatikan beberapa hal penting yaitu

a. Kebaikan moral dan fisik

Hal ini menjadi syarat yang harus diupayakan untuk dilaksanakan karena kebaikan moral dan kebaikan fisik akan mengakibatkan seorang calon tenaga kerja atau SDM mudah mengembangkan gagasan, ide dan pemikiran yang baik, cerdas dan berkualitas.

Teguh

Suripto

247
Mengenai hal ini Alloh telah menyampaikan tuntunannya didalam surat $\mathrm{Al}$ Qashash : 26, dan tuntunan dari rosululloh seperti tercantum dalam : Hadits riwayat : Tirmidzi dan Ibnu Majah.

b. Kebaikan akal dan pikiran

JURNAL EKONOMI SYARIAH INDONESIA, Volume II, No.2 Desember 2012 
Hal yang kedua tentang kebaikan akal dan pikiran. Kebaikan ini akan mengakibatkan seseorang menjadi lebih cerdas, tidak mudah putus asa, dan bersemangat untuk tetap maju dan berkembang menjadi lebih baik. Mengenai hal ini Alloh telah memebrikan penjelasan di dalam QS Yusuf : 55.

2. Pemberian tugas dan kewajiban kepada setiap karyawan hendaknya dijalankan dengan sebaik - baiknya, dan tidak dijadikan beban, sehingga mereka mampu menjalankan tugas dan kewajibannya dengan baik, hal ini sesuai dengan firman Alloh SWT, dalam surat Al Maidah : 7, yang artinya sebagai berikut :

"Kami tidak membebani seseorang melainkan menurut kesanggupannya, dan pada sisi kami ada suatu kitab yang membicarakan kebenaran, dan mereka tidak dianiaya" (Al Mu'minuun : 62)

Dari ayat tersebut dijelaskan bahwa Alloh tidak membebani hidup manusia dengan hal - hal yang melampaui batas. Alloh memberikan prinsip - prinsip yang positif dan memperbolehkan manusia memperoleh / mendapatkan kenikmatan. (Afzalur Rahman, 1998)

3. Pelatihan dan pengembangan hendaknya mampu memberikan kemajuan pada pelaksanaan tugas karyawan, oleh karena itu pelatihan dan pengembangan karyawan hendaknya meliputi program yang berorientasi pada perbaikan moral dan pelaksanaan kerja karyawan.

Disamping itu, sebagai seorang karyawan, dalam pandangan ekonomi Islam,terdapat beberapa hal yang harus diperhatikan diantaranya : (Mouris, 1995)

a. Setiap Individu atau karyawan harus memahami bahwa mereka tidak akan berubah dan berkembang kecuali dia berupaya untuk mengembangkan diri mereka sendiri.

b. Keyakinan individu yang beruntung adalah mereka yang hari ini lebih baik dari hari kemarin, dan individu yang celaka adalah mereka yang hari ini lebih buruk dari hari kemarin

c. Setiap individu bertanggung jawab atas apa yang dilakukan, jika berbuat baik akan mendapatkan kebaikan, sedangkan apabila berbuat buruk maka akn mendapatkan keburukan

d. Adanya kesadaran untuk menghindari perbuatan yang buruk, dan selalu menjalankan perbuatan yang baik ( Amar ma'ruf nahi munkar)

Dengan adanya keseimbangan perilaku ini, yaitu antara perilaku karyawan dengan perilaku perusahaan maka, keseimbangan yang diharapkan dalam Islam akan terwujud. Dan itulah sebenarnya tujuan pengelolaan SDM dalm prespektif Islam.

D. Kesimpulan

1. Agama Islam merupakan salah satu hal yang memberikan pengaruh yang besar terhadap perkembangan masyarakat terutama dalam hal budaya dan nilai- nilai sosial di dalamnya (Social values). Pengaruh dari nilai - nilai yang ada di masyarakat merupakan

Manajem en SDM keyakinan dan nilai - nilai yang dominan dari masyarakat yang

\section{8}


luas, misalnya kebebasan individu, kolektivisme, kesopanan, kebersihan dan sebagainya.

2. Pengelolaan SDM atau Manajemen SDM sesuai dengan pola konvensional, hanya mengedepankan sifat keduniawian saja, belum memandang kebutuhan rohaninya. Sehingga karyawan hanya menjadi obyek perusahaan dan belum menjadi subyek bagi perusahaan. Dengan penerapan Manajemen SDM secara islama, karyawan akan menjadi subyek bagi perusahaan sehingga mereka mampu berpartispasi aktif bagi kemajuan perusahaan.

3. Sistem ekonomi Islam dalam menerapkan manajemen SDM, mendasarkan pada keselarasan atau keseimbangan yang dapat dilakukan diantara kebutuhan materialdan etika manusia. Sistem Ekonomi Islam tidak melupakan ciri pokok kemajuan manusia, yang bergantung kepada sejauh mana lancarnya koordinasi dan keharmonisan diantara aspek moral dan material dalam kehidupan manusia.

4. Dalam pandangan islam seorang karyawan harus memiliki perilaku diantaranya :

a. Setiap Individu atau karyawan harus memahami bahwa mereka tidak akan berubah dan berkembang kecuali dia berupaya untuk mengembangkan diri mereka sendiri.

b. Keyakinan individu yang beruntung adalah mereka yang hari ini lebih baik dari hari kemarin, dan individu yang celaka adalah mereka yang hari ini lebih buruk dari hari kemarin

c. Setiap individu bertanggung jawab atas apa yang dilakukan, jika berbuat baik akan mendapatkan kebaikan, sedangkan apabila berbuat buruk maka akn mendapatkan keburukan

d. Adanya kesadaran untuk menghindari perbuatan yang buruk, dan selalu menjalankan perbuatan yang baik ( Amar ma'ruf nahi munkar).

5. Pada akhirnya Alloh SWT, berfirman dalam surat Al baqarah : 269, yang artinya :

"Alloh menganugerahkan Al Hikmah (kepahaman yang dalam tentang Al Quran dan As Sunnah) kepada siapa yang dia kehendaki. Dan barang siapa dianugerahi Al Hikmah itu, dia benar - benar telah dianugerahi Al Hikmah itu, ia benar - benar telah dianugerahi karunia yang banyak. Dan hanya orang - orang yang berakalah yang dapat mengambil pelajaran." (Al Baqarah : 269).

Surat ini memberikan penjelasan kepada kita, bahwa kita diberikan akal dan pikiran yang lebih baik dari makhluk yang lain, oleh karena itu Teguh karyawan harus dapat mengambil pelajaran - pelajaran dalam Suripto kehidupannya, baik di kantor maupun di rumah. 


\section{Daftar Pustaka}

Bohlander Snell, (2004), Managing Human resources, Thomson, South Westernm United State of America.

Faustino Cardoso Gomes, (2000), Manajemen Sumber Daya Manusia, Andi Offset, Yogyakarta

Hani Handoko, (1999), Manajemen, BPFE, Yogyakarta

Hani Handoko, (1998), Manajemen Personalia dan Sumber Daya Manusia, BPFE, Yogyakarta

Juani Swart, et.al, (2005), Human Resources Development, Elsevier, Heinemann, Oxford

Afzalur Rahman, (1995), Doktrin Ekonomi Islam, Jilid 1, Dana Bhakti Wakaf, Yogyakarta

Rafik issa beekun, (1997), Islamic Business Ethics, hemdon, Virginia.

Larasati Oktina, Fuad Mas'ud, Praktik Penerapan Manajemen Islam Pada Perusahaan (Studi Pada PT. Toha Putra Semarang), Jurnal Manajemen Islam

Ruslan Abdul Ghofur, Manajemen Sumber Daya Manusia (MSDM) Dalam Prespektif Ekonomi Syariah: Studi Kritis Aplikasi MSDM Pada lembaga Keuangan Publik Islam, IAIN Raden Intan Bandar Lampung

Prawiranegara Sjafruddin, 1966, "Peran Agama dan Moral" dalam pembangunan masyarakat dan ekonomi, Indonesia, Djakarta, Jakarta : Bulan Bintang.

Antonio Muhammad Syafii, 2003, Islamic Bank in Indonesia, Thesis of doctor of Philosophy degree, Melbourne, The University of Melbourne.

Abu Sinn, Ibrahim, 2006, Manajemen Syariah, Jakarta : Raja Grafindo Persada

Hasyim Junaidah, 2009, Islamic Revival in Human Resource Management Practices Among Selescted Islamic Organizations in Malaysia, Vol. 2 no. 3 pp $251-267$

Kiggundu, Moses N, 1989, Managing Organization in Developing Countries : an operational and strategic approach, Kumarian Press, Inc.,West Harfford. 